\title{
Notes on two lesser known Codonopsis (Campanulaceae) from eastern Himalaya, India
}

\author{
Dash S.S. ${ }^{1 *}$, Lahiri S. ${ }^{2}$, Ghosh A. ${ }^{3}$ \& B.K. Sinha ${ }^{1}$ \\ ${ }^{1}$ Botanical Survey of India, CGO Complex, Salt Lake, Kolkata, West Bengal - 700 064, India \\ ${ }^{2}$ Central National Herbarium, Botanical Survey of India, Howrah, West Bengal - 711 103, India \\ 3UGC CAS Department of Botany, The University of Burdwan, Golapbag, Burdwan, West Bengal - 713 104, India \\ ${ }^{\star}$ E-mail: ssdash2002@gmail.com
}

\begin{abstract}
Two lesser known species of Codonopsis Wall. (Campanulaceae), viz. C. benthamii Hook.f. \& Thomson and C. subsimplex Hook.f. \& Thomson were collected after a lapse of more than a century from Sikkim Himalaya, India. The authors evaluated the phenology of the above species in the last hundred years which shows a significance alteration. In this paper, information about the taxonomy, habitat, distribution and phenology are discussed along with photographic images.
\end{abstract}

Keywords: Codonopsis benthamii, C. subsimplex, Phenology, Rediscovery, Sikkim, Taxonomy.

\section{Introduction}

The genus Codonopsis Wall. (Campanulaceae) is widely distributed in temperate to alpine region of Asia and Europe and includes about 64 species (Hong, 2015b). The genus includes perennial erect herbs or herbaceous twiners characterized by solitary and large campanulate flowers, generally with a peculiar foul odour (Haridasan \& Mukherjee, 1996; Hong, 2015a; Mabberley, 2017). Clarke (1881) reported 10 species of Codonopsis from the then British India under two sections: Campanumoea Blume and Cyclocodon Griff. Recent field studies in Himalayas (Dash, 2018), revealed the occurrence of 15 species in India, of which $C$. ovata Benth., C. clematidea (Schrenk) C.B.Clarke and $C$. rotundifolia Benth. show an extended distribution in Western Himalaya, while the rest 12 species are restricted to eastern Himalaya.

Received: 14.09.2019; Revised \& Accepted: 10.04 .2020

Published Online: 30.06 .2020
During field explorations in the East district of Sikkim, two species of Codonopsis were came across in Kyongnosla Alpine Sanctuary. After consulting the relevant literature (Hooker \& Thomson, 1858; Clarke, 1881; Komarov, 1908; Hong et al., 2011; Hong, 2015a), type specimens, protologue and other specimens housed in different herbaria (A, ARUN, ASSAM, BSHC, CAL, DD, E, GH, K, LWG, PE), they were identified as $C$. benthamii Hook.f. \& Thomson and C. subsimplex Hook.f. \& Thomson. C. benthamii is rediscovered after 110 years while C. subsimplex after a gap of 50 years after their last collection in India.

\section{Material and Methods}

Flowering specimens were collected from Kyongnosla Alpine Sanctuary (East district, Sikkim, India) and voucher specimens were prepared as per standard procedure (Jain \& Rao, 1977). Photographs were taken in field with a Sony HX 400V camera. The micromorphological characters of flowers were studied using stereo-zoom microscope (Olympus SZ61, Japan). Detailed description was based on field observations and herbarium specimens (A, ARUN, ASSAM, BSHC, CAL, DD, E, GH, K and LWG; acronyms as per Thiers, 2020 continuously updated). To evaluate the change in flowering time of these two species in the last hundred years, Primack et al. (2004) was followed.

\section{Taxonomic treatment}

Codonopsis benthamii Hook.f. \& Thomson, J. Proc. Linn. Soc., Bot. 2: 14. 1857. Lectotype 
(designated by Hong, 2010): INDIA, Sikkim, Lachen, 2740 m, 31.07.1849, J.D. Hooker s.n. (K [K000814213 digital image!]).

Fig. 1

Erect foetid herbs. Stems 18-90 cm long, ascending, scandent, branched, sparsely hairy. Leaves alternate or nearly opposite; petioles 6-35 mm long, sparsely villous; lamina broadly ovate or ovate-lanceolate, $3-8 \times 1.5-5.5 \mathrm{~cm}$, acute or acuminate at apex, cuneate at base, irregularly lobed along the margins, crenate, deep green and sparsely puberulous adaxially, pale green and densely hirsute abaxially, with a prominent midrib, 4-5-nerved. Flowers solitary, terminal; pedicels $3.5-5 \mathrm{~cm}$ long, villous. Calyx tube obconic, 14-20 mm long, adnate to half of the hypanthium, 10-ribbed; lobes ovate, 10-13 $\times 4-7 \mathrm{~mm}$, acute at apex, glabrous, rarely sparsely hispidulous, denticulate towards apex, ciliate. Corolla tubular, narrowly campanulate, somewhat constricted in the middle, $17-30 \times 13-20 \mathrm{~mm}$, yellow-green with dull purplish veins, glabrous outside, brown spotted inside; lobes five, triangular, 2.5-4 mm long, acute at apex. Stamens 5; filaments 5-9 mm long, wholly villous and narrowly dilated at base; anthers dorsally setose, 4.5-5.5 mm long, monothecal, dorsifixed. Ovary semi-inferior; style c. $7 \mathrm{~mm}$ long, densely ciliate; stigma 3-lobed, creamy white, recurved, glabrous. Capsules globose, with persistent calyx.

Flowering \& fruiting: Flowering and fruiting from July to September.

Habitat: It grows in the alpine scrub forest, on soil surface, usually associated with Cynoglossum wallichii G.Don (Boraginaceae), Gypsophila cerastoides D.Don (Caryophyllaceae), Meconopsis paniculata (D.Don) Prain (Papaveraceae), Strobilanthes wallichii Nees (Acanthaceae), etc.

Distribution: India, Bhutan, China, N. Myanmar and Nepal.

Specimens examined: INDIA, Sikkim, East district, Kyongnosla Alpine Sanctuary, N 27 22'30.69", E 88 43'28.35", 3336 m, 03.07.2018, S. Lahiri E S.S. Dash 86684; s.loc., 2740-3350 m, 1861, J.D. Hooker s.n.; Yakla, 3050 m, 20.10.1869, C.B. Clarke
10224; Ibid., 15.10.1869, C.B. Clarke 9879; Gangtok, 09.08.1877, G. King 4439; Ibid., 08.08.1877, G. King's Collector 4440; Chola Range-Nathu La, 4270, 29.09.1892, G.A. Gammie 1322; Lachen, 2440 m, Sept-October 1909, Ribu \& Rhomoo 3016; Selu Valley, 3050 m, 03.09.1892, G.A. Gammie s.n. (CAL).

Notes: Codonopsis benthamii closely resembles $C$. tubulosa Kom. and C. vadsea S.S.Dash \& A.A.Mao, but differentiated by its foetid smell and larger leaves (Dash \& Mao, 2011). Lidén and Adhikari (2019) mentioned the occurrence of $C$. benthamii from east of Anini in Upper Dibang valley of Arunachal Pradesh, but without giving any collection details.

Codonopsis subsimplex Hook.f. \& Thomson, J. Proc. Linn. Soc., Bot. 2: 16. 1857. Lectotype (designated by Hong, 2010): INDIA, Sikkim, Lachen, 4270 m, 15.07.1849, J.D. Hooker s.n. (K [K000814205 digital image!]).

Fig. 2

Erect foetid herbs. Stems 16-40 cm long, ascending, almost glabrous or sparsely white-villous, red. Leaves alternate or almost opposite on branches; petioles $0.4-4.2 \mathrm{~cm}$ long, glabrous or sparsely white villous; lamina broadly ovate, $2.5-10 \times 2-5 \mathrm{~cm}$, acute or slightly obtuse at apex, cuneate or rounded at base, crenate or dentate along margin, deep green and hispidulous adaxially, pale green and hispidulous abaxially, midrib prominent, hirsute along veins. Cymes terminal, 2-4-flowered; pedicels $3.5-5 \mathrm{~cm}$ long, villous. Calyx tube adnate to whole hypanthium; lobes ovate, almost as long as corolla, $12-15 \times 5.5-8 \mathrm{~mm}$, hirsute abaxially, margin denticulate, ciliate, acute at apex. Corolla campanulate, $10-22 \times 11-18 \mathrm{~mm}$, inflated at base and narrowed from middle, slightly revolute at apex, greenish-yellow, glabrous and lustrous outside; lobes ovate-deltoid, 2-3 mm long, obtuse at apex. Stamens 5; filaments 3-4.5 mm long, glabrous, slightly dilated at base; anthers 5-6 mm long, linear-oblong, glabrous, yellow. Ovary semi-inferior; style erect, c. 6 mm long, sparsely ciliate; stigma lobe ovoid, recurved. Capsules obovoid, gradually narrowed towards base, with persistent calyx. 


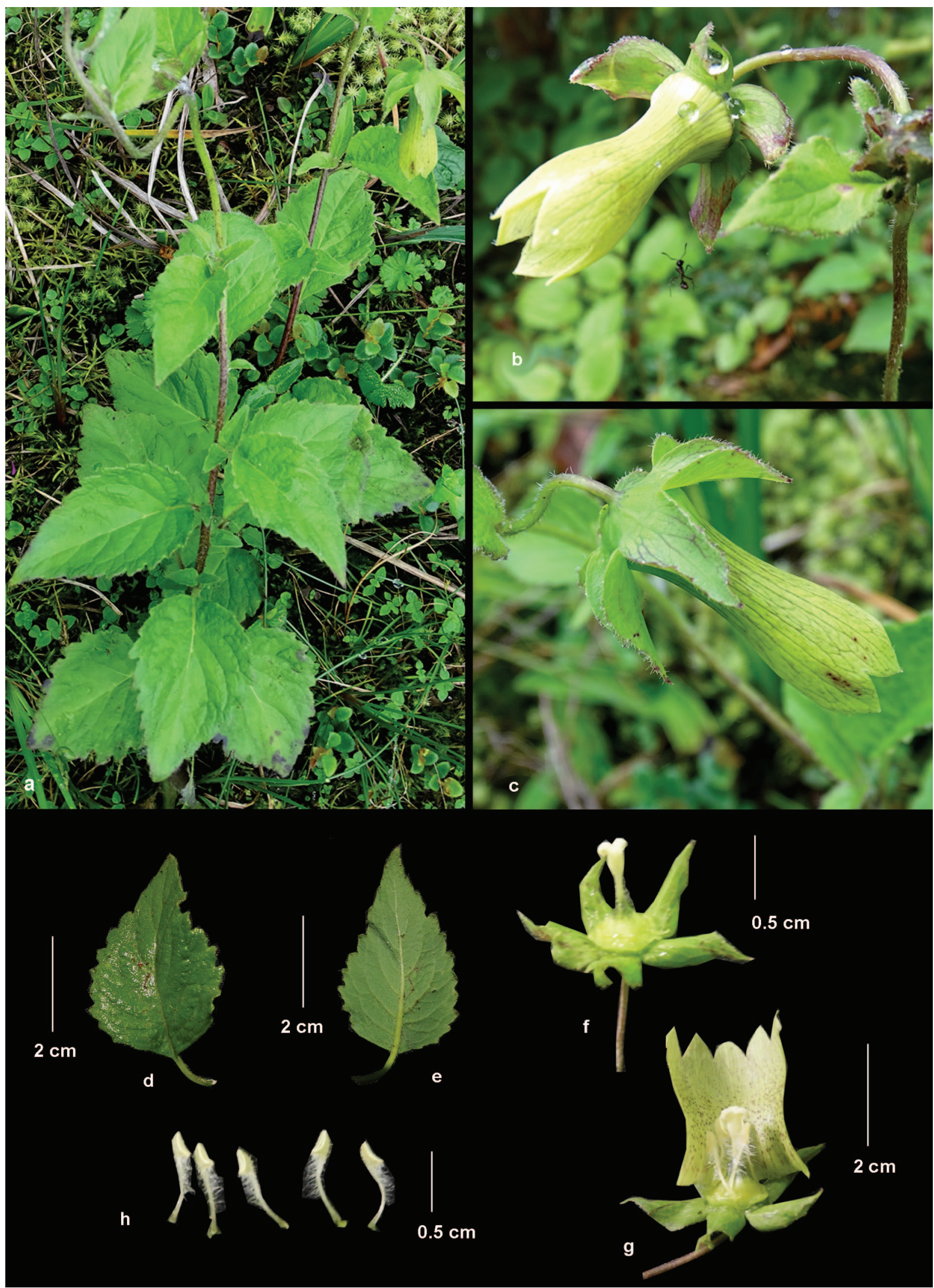

Fig. 1. Codonopsis benthamii Hook.f. \& Thomson: a. Habitat; b \& c. Flowering twig; d. Leaves-adaxial surface; e. Leaves-abaxial surface; f. Gynoecium with calyx; g. Corolla-spilt open; h. Stamens (from S. Lahiri \& S.S. Dash 86684; photos by Subhojit Lahiri). 


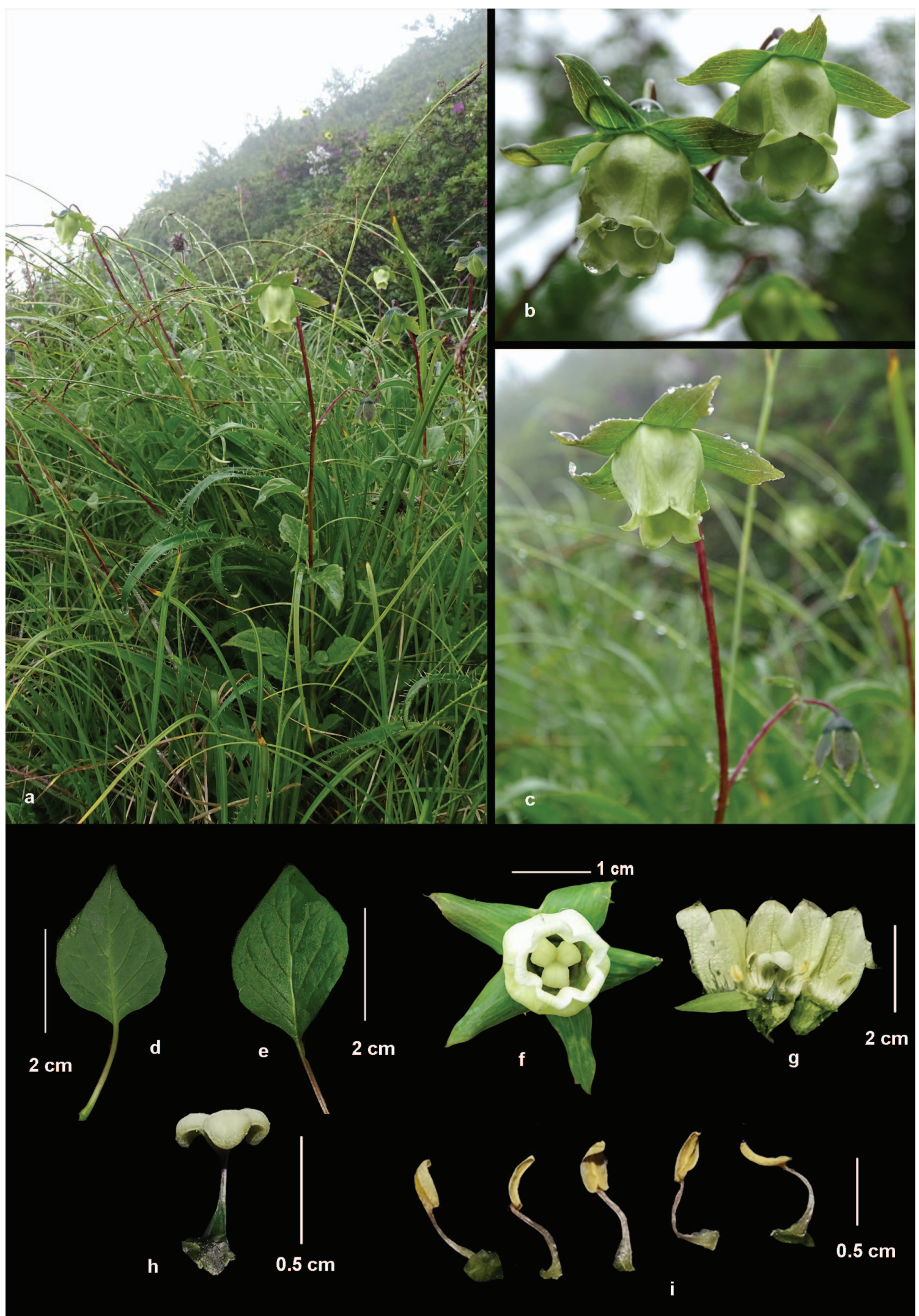

Fig. 2. Codonopsis subsimplex Hook.f. \& Thomson: a. Habitat; b \& c. Flowering twig; d. Leaves-abaxial surface; e. Leaves-adaxial surface; f. Flower-front view; g. Corolla (spilt open); h. Gynoecium; i. Stamens (from S. Lahiri \& S.S. Dash 85743; photos by Subhojit Lahiri). 


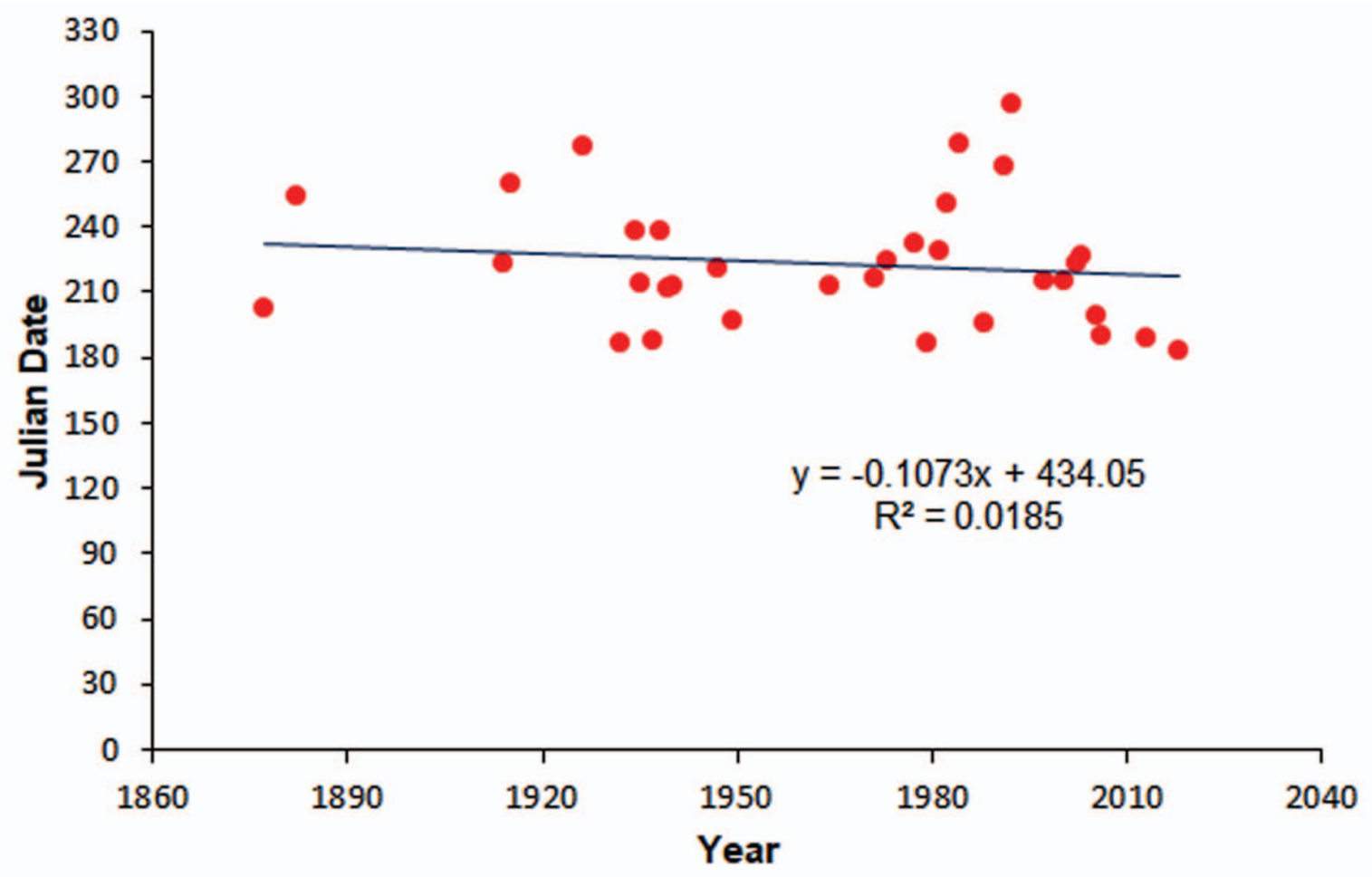

Fig. 3. Flowering phenology time of Codonopsis benthamii Hook.f. \& Thomson over 100 years (Smoothed best fit line with 95\% confidence interval).

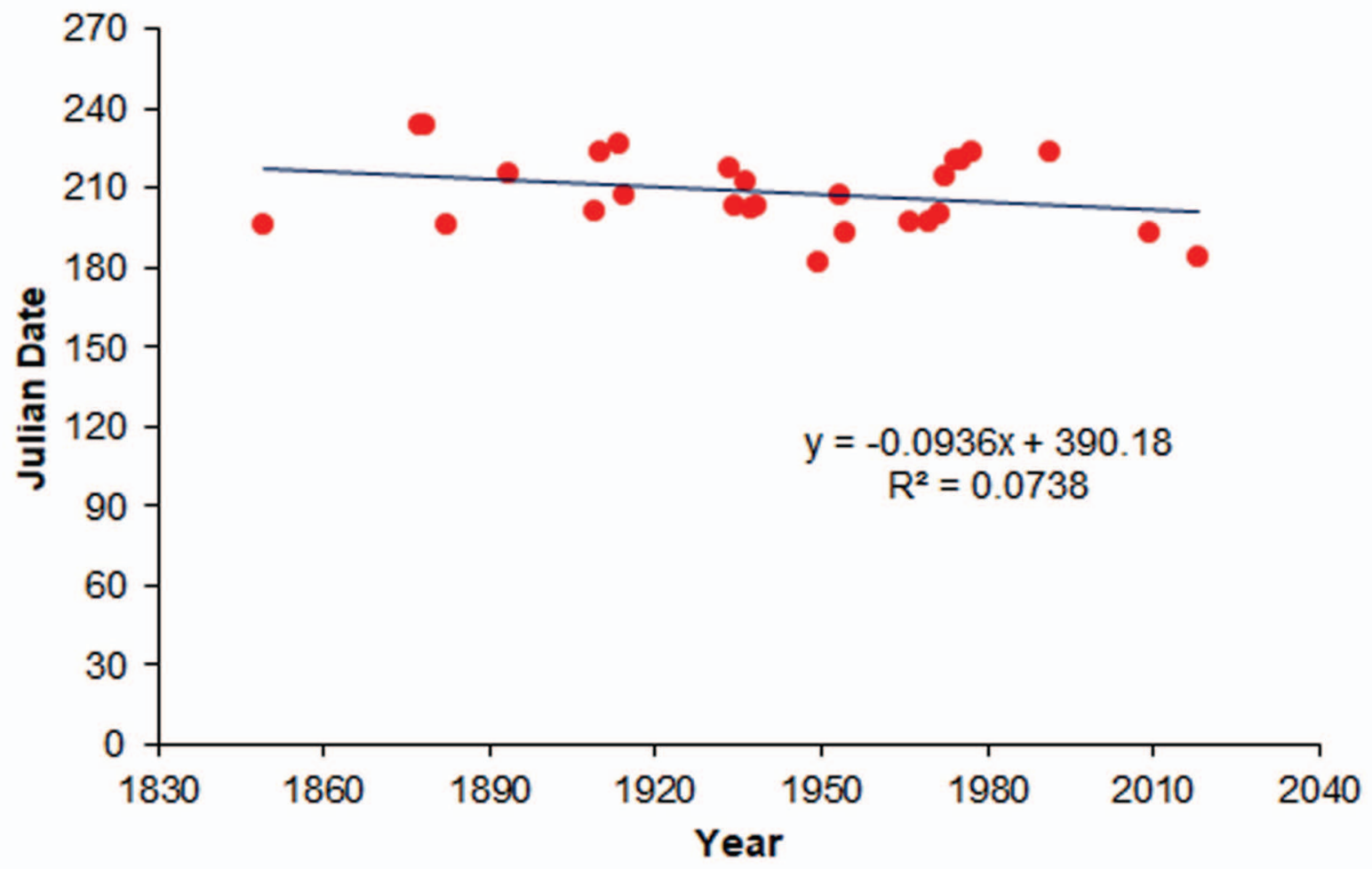

Fig. 4. Flowering phenology time of Codonopsis subsimplex Hook.f. \& Thomson over 100 year (Smoothed best fit line with $95 \%$ confidence interval). 
Flowering \& fruiting: Flowering and fruiting from July to September.

Habitat: It grows in the alpine scrub forest, in association with Corydalis juncea Wall. (Fumariaceae), Ligularia amplexicaulis DC. (Asteraceae), Gentiana stylophora C.B.Clarke (Gentianaceae), Morina nepalensis D.Don (Dipsacaceae), Rhododendron setosum D.Don (Ericaceae), etc.

Distribution: Bhutan, China, North India and Nepal. Specimens examined: INDIA, Sikkim, East district, Kyangnosla Alpine Sanctuary, N 27 23'37.59", E 88 45'23.19", 3965 m, 03.07.2018, S. Lahiri \& S.S. Dash 85743; Ibid., 3350 m, 07.10.1870, C.B. Clarke 12542; Ibid., 3350 m, 08.10.1870, C.B. Clarke 13450; s.loc., 4750 m, 04.08.1893, Cummins s.n.; Ibid., 08.12.1903, Prain's Collector 267; Sherabthang, 3960 m, 13.08.1910, W.W. Smith 4298; s.loc., 12.08.1910. $W . W$. Smith 4250; Zemu Valley, $3960 \mathrm{~m}$, 20.07.1909, W.W. Smith \& G.H. Cave 1653 (CAL).

Notes: Codonopsis subsimplex is close to $C$. gongshanica Q.Wang \& D.Y.Hong but differentiated by much smaller leaf, shorter petiole and with a solitary flower, smaller calyx lobes and pale purple corolla which has dark purple ring just below the throat.

\section{Observation on phenology}

Alteration of flowering time is considered the most sensitive indicator in the herbaceous species (Tilman \& Haddi, 1992; Walker et al., 1999) and has the potential to predict the effects of patterns of climatic change (Kittel, 1998; Parmesan \& Yohe, 2003; Root et al., 2003) of a region. The authors have attempted to infer the change in flowering time of $C$. subsimplex and C. benthamii over a period of 100 years by analysing the herbarium specimen data of the last century collected from alpine regions with the recent field observations and collections. On comparison with current flowering dates with herbarium information (1849-2018), simple linear regression analysis of predicted and observed values of flowering time revealed significant deviation in these two species (Figs. $3 \&$ 4) during the last 100 years. In both of the species Julian dates of the collected material showed negative correlation with years. The value for correlation coefficient for $\mathrm{C}$. benthamii and C. subsimplex is $\mathrm{r}=0.13$ and $\mathrm{r}=0.27$, respectively, which indicates a significantly negative correlation between the year and days of flowering at the level $P<0.05$. The scrutiny of herbarium data shows the mean flowering period of $C$. benthamii is advanced by $43.05 \pm 4.31$ days while the mean flowering period of C. subsimplex is advanced by $25.78 \pm 2.91$ days from its usual time of flowering of late July to August. The early flowering of C. benthamii and C. subsimplex may be attributed to the change in temperature in last 100 years and can be considered as indicator of climate change.

\section{Acknowledgements}

Authors are thankful to Director, Botanical Survey of India, Kolkata for facility; Department of Forest, Government of Sikkim for giving permission and logistic support and The Ministry of Environment, Forest \& Climate Change (MoEF \& CC), New Delhi for the financial Assistance (Project no. NMHS/2015-16/LG-05) under "National Mission on Himalayan Studies” (NMHS) Scheme.

\section{Literature Cited}

CLARKE C.B. 1881. Campanulaceae. In: HOOKER J.D. (eds.), Flora of British India. Volume 3. Spottiswood \& Co. London. pp. 421-442.

DASH S.S. \& A.A. MAO 2011. A new species of Codonopsis Wall. (Campanulaceae) from Arunachal Pradesh, India. Nelumbo 53: 17-20.

DASH S.S. 2018. An appraisal of genus Codonopsis Wall. (Campanulaceae) in India. Abstracts in International Symposium on Conservation of Angiosperm Diversity: Hidden Treasure of Today and Tomorrow. p. 55.

HARIDASAN V.K. \& P.K. MUKHERJEE 1996. Campanulaceae. In: HAJRA P.K. \& M. SANJAPPA (eds.). Fascicles of Flora of India. Volume 22. Botanical Survey of India, Kolkata. pp. 23-118.

HONG D.Y. 2010. Taxonomic Notes on Chinese Campanulaceae. Novon 20(4): 420-425.

HONG D.Y. 2015a. A monograph of Codonopsis and allied 
genera (Campanulaceae). Science Press, Beijing. p. 256.

HONG D.Y. 2015b. Campanulaceae. In: HANG S., WATSON M.F., WEN J. \& X.C. CHANG (eds.), Flora of Pan Himalaya. Volume 47. Cambridge Universiy Press, Cambridge, pp. 93-166.

HONG D.Y., SONG G., LAMMERS T.G. \& L.L. KLEIN 2011. Codonopsis. In: WU Z.G., RAVEN P. \& D.Y. HONG (eds.), Flora of China. Volume 19. Science Press, Beijing \& Missouri Botanic Garden Press, St. Louis. pp. 513-526.

HOOKER, J.D. \& T. THOMSON 1858. Praecursores ad Floram Indicam, being sketches of the natural families of Indian plants, with remarks on their distribution, structure, and affinities. Journal of the Proceedings of the Linnean Society of London 2: 1-29.

JAIN S.K. \& R.R. RAO 1977. A handbook of field and herbarium methods. Today and Tomorrow's Printers and Publishers, India. p. 157.

KITTEL T.G.F. 1998. Effects of climatic variability on herbaceous phenology and observed species richness in temperate montane habitats, Lake Tahoe Basin, Nevada. Madroño 45: 75-84.

KOMAROV V.L. 1908. Prolegomena ad Floras Chinaenec non Mongoliae Codonopsis Wall. Trudy Imperatorskago S. Peterburgskago Botaniceskago Sada 29(1): 102-124.

LIDÉN M. \& A. ADHIKARI 2019. Floristic report from Upper Dibang (Arunachal Pradesh) with several species new to India. Pleione 13(1): 175-187.
MABBERLEY D.J. 2017. Mabberley's plant-book: A portable dictionary of plants, their classifications and uses. Fourth edition. Cambridge University Press, London, p. 215.

PARMESAN C. \& G. YOHE 2003. A globally coherent fingerprint of climate change impacts across natural systems. Nature 421: 37-42.

PRIMACK D. IMBRES C., PRIMACK R.B., MILLERRUSHING A.J. \& P.D. TREDICI 2004. Herbarium specimens demonstrate earlier flowering times in response to warming in Boston. American Journal of Botany 91: 1260-1264.

ROOT T.L., PRICE J.T., HALL K.R., SCHNEIDER S.H., ROSENZWEIG C. \& J.A. POUNDS 2003. Fingerprints of global warming on wild animals and plants. Nature 421: 57-60.

TILMAN D. \& E.I. HADDI 1992. A Drought and biodiversity in grasslands. Oecologia 89: 257-264.

THIERS B. 2020. Index Herbariorum: A global directory of public herbaria and associated staff. New York Botanical Garden's Virtual Herbarium (continuously updated). Available at: http://sweetgum.nybg.org.

WALKER M.D., WALKER D.A., WELKER J.M., ARFT A.M., BARDSLEY T., BROOKS P.D., FAHNESTOCK J.T., JONES M.H., LOSLEBEN M., PARSONS A.N., SEASTEDT T.R. \& P.L. TURNER 1999. Long-term experimental manipulation of winter snow regime and summer temperature in arctic and alpine tundra. Hydrol Process 13(14-15): 2315-2330. 